\title{
Certainty into doubt: 25 years of nuclear debate
}

\author{
Alan Cottrell
}

The Nuclear Power Decisions: British Policies, 1953-78. By Roger Williams. Pp.365. (Croom Helm: London, 1980.) £19.95. Available from Biblio Distribution Centre, Totowa, New Jersey, \$49.

THERE IS a saying in the nuclear industry that the reactor you choose is always the best one. It becomes the best one because you work on it, solve its problems, improve it, develop and adapt a whole technology to it, all of which gives it an edge over its rivals. There are certainly grains of truth in this, but the irony is that different countries have different 'best' reactors and hang on to their choices grimly through thick and thin. Today we have each of the three original reactor-producing countries firmly entrenched in its own concepts of thermal reactors: the gas-cooled types, Magnox and AGR, for the British; the light-water ones, PWR and BWR, for the Americans; and the heavy-water one, CANDU, for the Canadians.

It is interesting to follow these deep, insurmountable, trenches back in time to their earliest beginnings in the 1940 s as slight traces across the smooth face of the then infant nuclear era. There were the Americans using light-water cooling in their early Hanford reactors, choosing it for its simplicity and because they had the empty spaces in which to site these possibly dangerous plants. From this early background they went on to light-water pressurized reactors for propelling submarines, out of which grew the modern pressurizedwater and boiling-water civil reactors. Again there were the British, with their lack of large rivers for coolant in very remote and unpopulated regions, choosing gascooling for their early Windscale military reactors, which likewise set them firmly in their own groove; and yet again there were the Canadians, keen to make the best use of natural uranium and so being led to heavywater, to which they became equally heavily addicted. Only the French, in switching from gas cooling to light-water cooling, dared to jump over into another trench.

Much of this is brought out in Roger Williams's splendid book, The Nuclear Power Decisions, which discusses the major British decisions in the civil nuclear field, and the way they were made, between 1953 and 1978. Mostly, the book deals with the history of the Advanced Gas-cooled Reactor (AGR) - of how, despite its various imperfections and vicissitudes, it
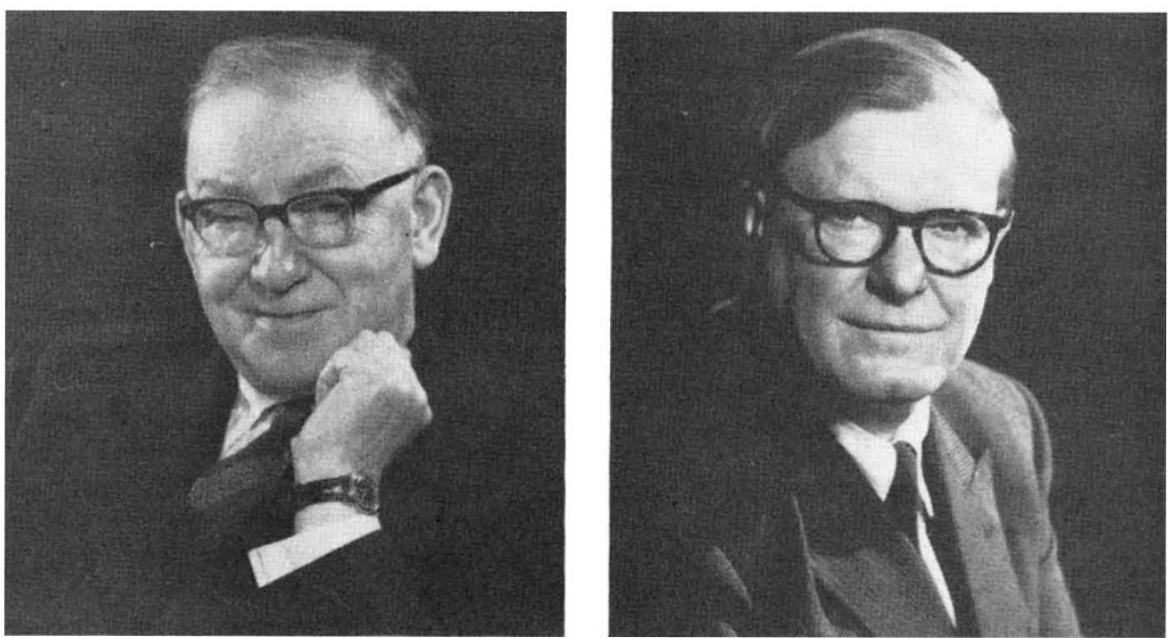

Sir John Cockcroft (left) and Lord Penney "heroes" of the 1950s and 60s.

successfully fought off all threats from every water-cooled rival, basically because it was a gas-graphite reactor, a British concept with British technology and expertise, a direct descendant of the Windscale, Calder Hall and Magnox reactors. Williams takes the reader carefully and clearly through the history of this, giving full weight to all the technical, economic, political and, not least, personal factors involved in the decisions. The sound of those old debates of the 1950s and 60s, now half-forgotten, comes thundering back with the reminders of the great speeches by the heroes of that period - Hinton, Penney, Cockcroft, Plowden, Sherfield, Coleraine, Stanley Brown and others; as well as the clash of argument between the AEA and the CEGB. We are also reminded of the amazing surefootedness of that early period, of the launching in the mid-1950s of a huge programme of Magnox reactors even though their prototype, Calder Hall, was still one year away from completion. Contrast that with the snail-like approach we are making today towards the Fast Breeder Reactor. How did we lose our nerve? Williams is too polite to say but he does make a vigorous plea in his final chapter for a system of public accountability that would make civil nuclear energy as acceptable to the general public in the 1980 s as it so obviously was in the 1950 s.

Perhaps the difficulties of the AGR had something to do with it, causing us to doubt whether our 'best' really was the best of bests. Williams takes the reader through the dense jungle of AGR politics with immense skill and clarity, especially in regard to the economic and political factors. Despite the intentionally nontechnical nature of the book, more could perhaps have been made of the technical differences between AGR and the water reactors, and their significance, particularly from the point of view of safety, for these factors do have important weight in the decision-making. Nevertheless, the account is a very fair and well-balanced one, which is no mean feat in a field where emotions run so high that one distraught civil servant felt impelled to complain that it was impossible for anyone to remain impartial where the choice of reactors is concerned.

The final section of the book deals with the 1978 Windscale decision. This is not only a change of subject - the expansion of the nuclear reprocessing plant - but even more a reflection of the change of mood since the 1950s. No longer is there the gungho approach of the early White Papers on reactor programmes. Instead we are in the era of doubt, of public enquiries, of $\mathrm{Mr}$ Benn's hesitations, of the cautionary remarks of the Flowers Report, and of the campaigns by the Friends of the Earth and other anti-nuclear groups. So much has the native hue of nuclear resolution been sicklied o'er by the pale cast of thought. And this leads to Williams's final chapter on public accountability and his "conviction that Britain can have a much more successful industrial future than she has had an immediate past, especially where nuclear power is concerned". A book strongly to be recommended.

Sir Alan Cottrell is Master of Jesus College, University of Cambridge. 